\title{
Predictors of post prandial glucose level in diabetic elderly
}

\author{
Ni Putu Wulan Purnama Sari ${ }^{1}$, Maria Manungkalit ${ }^{2}$ \\ ${ }^{1}$ Department of Palliative Nursing, Widya Mandala Catholic University Surabaya, Indonesia \\ ${ }^{2}$ Department of Medical-Surgical Nursing, Widya Mandala Catholic University Surabaya, Indonesia
}

\begin{abstract}
Article Info
Article history:

Received Mar 26, 2019

Revised Apr 10, 2019

Accepted May 24, 2019

\section{Keywords:}

Functional status

Post prandial glucose

Self-care

Sleep quality

Stress

ABSTRACT

Post prandial glucose (PPG) level describes the speed of glucose absorption after two hours of macronutrient consumption. By knowing this, we could get the big picture of insulin regulation function and macronutrient metabolism in our body. In elderly, age-related slower glucose metabolism leads to diabetes mellitus (DM) in older age. This study aimed to analyze the predictors of PPG level in diabetic elderly which consist of functional status, self-care activity, sleep quality, and stress level. Cross-sectional study design was applied in this study. There were 45 diabetic elderly participated by filling in study instruments. Pearson and Spearman Rank correlation test were used in data analysis $(\alpha<.05)$. Results showed that most respondents were female elderly, 60-74 years old, had DM for 1-5 years with no family history, and only $33.33 \%$ respondents reported regular consumption of oral anti diabetes (OAD). Hypertension was found to be frequent comorbidity. Statistical analysis results showed that functional status, self-care activity, sleep quality, and stress level were not significantly correlated with PPG level in diabetic elderly (all $\mathrm{p}>\alpha$ ), therefore these variables could not be PPG level predictors. Other factors may play a more important role in predicting PPG level in diabetic elderly.
\end{abstract}

Copyright @ 2019 Institute of Advanced Engineering and Science. All rights reserved.

\section{Corresponding Author:}

Ni Putu Wulan Purnama Sari,

Department of Palliative Nursing,

Widya Mandala Catholic University Surabaya,

Jl. Raya Kalisari Selatan 1, Pakuwon City, Surabaya 60112, Indonesia.

Email: wulanpurnama@ukwms.ac.id

\section{INTRODUCTION}

Elderly are prone to non-communicable disease (NCD) due to the degenerative process happens in internal organs leads to the decreased function. The five major types of NCD are heart disease, stroke, cancer, diabetes mellitus (DM), and chronic lung disease; they are collectively responsible for almost $70 \%$ of all deaths worldwide [1]. Frailty is the most important predictor of death in older adults with DM [2]. DM is a metabolic disorder by sign of elevated blood glucose level until above normal range or hyperglycemia [3]. Age is one of the predisposing factors of DM in elderly [4]. DM prevalence in Indonesian elderly (above 65 years old) was 4.6\% [5]. Urbanization is one of the risk factor of DM. DM prevalence was higher in elderly who live in the city (14.7\%) compared to the village (7.2\%) (PERKENI, 2011) [6]. Other than urbanization, unhealthy life style (physical inactivity, unhealthy diet/high calory intake, tobacco use/smoking, and harmful use of alcohol), obesity, and sleep disturbance are also risk factor of DM [1, 7].

Being an elderly means individual has experienced various life stages, starting from newborn, infant, toddler, preschool, school, teenager, and adult, in which the changes happen physiologically and psychologically [8]. Functional status is a main predictor factor for several adverse outcomes in older adults with DM [2]. Older people with DM demonstrated a reduction in physical function or experienced functional impairment which threathening personal independence and quality of life. Long duration of DM also 
increases the loss of muscle function in older people and this may contribute to the underlying pathophysiological changes in frailty, disability and sarcopenia [2]. Functional status after DM has not been much studied but is in important because it relates to frailty which being the most important predictor of death in older adults with DM.

There are 7 types of self-care activities important for increasing glycemic control, such as: a) Healthy diet. b) Physically active. c) Blood glucose level monitoring. d) Consume OAD regularly. e) Good problem solving. f) Adaptive coping mechanism. g) Early detection of disease complication [9]. Other than for increasing control glycemic, these 7 types of self-care activities are important also for preventing physical limitation or disability which related to the functional status, and for rehabilitative function. Elderly with DM could make significant progress in their glycemic control by doing optimum self-care. Although this proposition is really promising, but their adherence to self-care at home remains a big question.

Sleep and circadian rhythm have important roles in regulating insulin production and sensitivity, glucose uptake and tolerance at night [10]. Sleep disturbance contributes to the risk factor of DM in elderly [11]. Elderly are prone to sleep disturbance because changes happen physiologically in the Central Nervous System (CNS) which regulating sleep-awake pattern, and general sensory problems which decrease the time sensitivity important for maintaining circadian rhythm [12]. Individuals who sleep less than 4 hours per night will experience impaired glucose tolerance if compare to others who sleep enough. A study in Sweden revealed that sleep disturbance in a healthy individual may cause impaired glucose metabolism and symphatovagal imbalance result in DM incidence in middle adult age (40-48 years old) [13]. Sleep quality in diabetic elderly is important to be identified.

Age-related changes in elderly may cause stress due to the adjustment process. Not only because of the adjustment to the new role as an elderly in the family and physical changes, elderly with NCD are also get stressors from the disease burden, such as disturbing signs and symptoms, diet restriction, continuous physical exercise requirement, drugs consumption, health routine check up, etc. [14]. DM may increase stress level in elderly both physically and psychologically. Under stress condition, the body responds by secreting cortisol hormone from the liver. This hormone is a dibetogenic agent because secreted cortisol will be metabolized (catabolism) in the muscular and adiposal tissue. Therefore cortisol causes an increase in blood glucose level physiologically. In a sick individual, in diabetic elderly for instance, the level of blood glucose worsen by the stress experienced. Whether stress level determines the level of PPG level in diabetic elderly still needs further investigation.

There were five pillars of DM management in Indonesia, one of which is blood glucose monitoring. Easy monitoring of glycemic control could be done by measuring periferal blood glucose level by using glucometer at home. There are 3 types of easy blood glucose test, namely: random, fasting, and post prandial glucose (PPG). Post prandial glucose (PPG) level describes the speed of glucose absorption after 2 hours of macronutrient consumption (200 kilocalories equal to 2 slices of plain bread). Glucose removal levels are considered normal if glucose levels return to normal range within 2 hours after it rises peakly in the first hour [15]. By knowing PPG level, we could get the big picture of insulin regulatory function and macronutrient metabolism in our body. The research question is whether functional status, self-care activity, sleep quality, and stress level could significantly predict the PPG level in diabetics elderly. This study aimed to analyze the predictors of PPG level in diabetics elderly which consist of functional status, self-care activity, sleep quality, and stress level, especially in those who live in the city. By knowing this study results we could modify the predictors/factors by various interventions so that PPG level in diabetics elderly could be optimized.

\section{RESEARCH METHOD}

This study utilized cross-sectional design. The population was all diabetic elderly under the responsibility of Mulyorejo Public Health Centre (PHC), Surabaya, amounted to 250 elderly in February 2019. Sample size was 45 , selected by purposive sampling. Sample criteria were medical diagnosis was confirmed by Mulyorejo PHC, and actively participated in the elderly community health group supervised by Mulyorejo PHC. Independent variables were functional status, self-care activity, sleep quality, and stress level which measured in orderly by ECOG performance status by Eastern Cooperative Oncology Group [16] with $r=1.0$ (no reliability analysis available because of single item), self-care inventory (revised version) by Annette M. La Greca [17] with r=.955-.975 and Cronbach Alpha=.525, Pittsburgh Sleep Quality Index (PSQI) [18] with kappa=0.75 and $\mathrm{p}<.001$, and SPST -20 by Ministry of Public Health, Thailand [19] with $\mathrm{r}=.460-.853$ and Cronbach Alpha=.950. Dependent variable was PPG level which measured by glucometer (new device, calibration procedure was unnecessary). All study instruments were valid and reliable. Pearson and Spearman Rank correlation tests were used in data analysis $(\alpha<.05)$. Ethical clearance was issued 
by Faculty of Medicine, Widya Mandala Catholic University Surabaya, with certificate number of 011/WM12/KEPK/T/2019.

\section{RESULTS AND DISCUSSION}

Most respondents were married female elderly, 60-74 years old, graduated from primary school, housewife with minimum monthly income (from family support). Table 1 explains the demographic variable of study respondents in details.

Table 1. Demographic characteristic

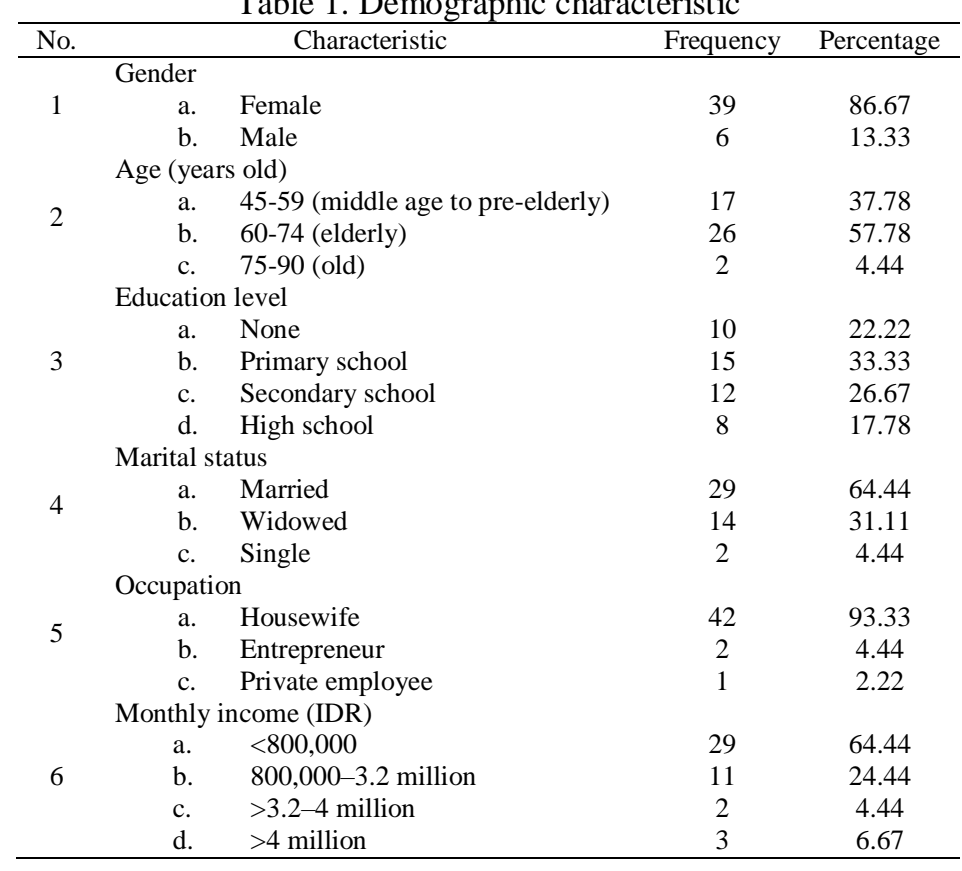

There are two key drivers of population ageing: a) The decline in fertility rates to below replacement levels, and b) A fall in mortality [20]. WHO (2015) categorized the age of old people into 3, namely: a) 60-74 years old=elderly. b) 75-90 years old=old, and c) More than 90 years old=very old [21]. Female aged 60-74 years old (elderly) were found to be the majority of respondents. Age is being one of the predisposing factors of NCD in elderly [4]. In 2017, population of elderly was $9.03 \%$ among 262 million of Indonesian citizen, in which female elderly held $9.53 \%$ while male elderly held $8.54 \%$ only, and female elderly had longer life expectancy than the males [22]. The remarkable improvements in life expectancy over the past century were part of a shift in the leading causes of disease and death. Among all the provinces in Indonesia, Province of Each Java, in which its capital is Surabaya, has sat in the 2nd rank in the country as the highest elderly population with $10.4 \%$ of the population [23]. Therefore, it is very common in Surabaya society today to found more female elderly with NCD, especially with DM in this study context.

Most respondents were primary school graduated. Education is a variable determining individual's living standard, together with housing, income, jobs, community, environment, civic engagement, health, life satisfaction, safety, and work-life balance. A previous study towards 30 elderly with DM in the working area of Mojo PHC, Surabaya, showed that education level was significantly but weakly correlated with quality of life (QOL) $(\rho=.218, \mathrm{p}=.002)$ which was determined by the individual living standard. Most respondents were not experienced any college life. If we could assume that the higher individual's educational background means the more information or knowledge about DM she/he has, it means most of study respondents had low DM-related knowledge. Another study results showed that senior age and poor education have a significant association with inadequate levels of health literacy [24]. A person's educational level accounted for $60 \%$ of his or her health literacy level [25]. Health literacy exerted an indirect effect on QOL (16\% of the variance), especially in type 2 DM [26].

Most respondents were housewife with family fully supported their monthly allowance, mostly less than IDR 800 thousand. World Bank has made 5 categories of socioeconomic class based on monthly income, namely: a) Low class=less than IDR 2.6 million. b) First middle class=IDR 2.6-5.2 million. 
c) Second middle class=IDR 5.21-7.8 million, d) Third middle class=IDR 7.81-13 million, and 5) fourth middle class=IDR 13,01-26 million [27]. Based on this standard, most study respondents belonged to low socio-economic class. Political and cultural factors have made women elderly experience cumulative economic barriers since youth making them short of resources and contributing to the deterioration in QOL [28].

Duration of DM was mostly 1-5 years with no family history. Only $33.33 \%$ respondent reported regular consumption of Oral Anti Diabetes (OAD), but 35.56\% respondents reported consuming no drug. Hypertension (HT) was found to be the most frequent comorbidity (53.33\%), but only $24.44 \%$ respondents reported consuming anti-HT drugs regularly. The majority was overweight with fat appearance. Table 2 explains the primary data of study respondents in details.

Table 2. Primary data

\begin{tabular}{|c|c|c|c|}
\hline No. & Characteristic & Frequency & Percentage \\
\hline \multirow{5}{*}{1} & Duration of DM (years) & & \\
\hline & a. $\leq 1$ & 11 & 24.44 \\
\hline & $>1-5$ & 19 & 42.22 \\
\hline & $6-10$ & 7 & 15.56 \\
\hline & d. $\quad \geq 11$ & 8 & 17.78 \\
\hline \multirow{3}{*}{2} & Family history of DM & & \\
\hline & a. Yes & 15 & 33.33 \\
\hline & b. No & 30 & 66.67 \\
\hline \multirow{8}{*}{3} & Comorbidity & & \\
\hline & a. Hypertension (HT) & 24 & 53.33 \\
\hline & Heart disease & 2 & 4.44 \\
\hline & Hypercholesterolemia & 16 & 35.56 \\
\hline & Stroke & 4 & 8.89 \\
\hline & Others (asthma, Gout & 5 & 11.11 \\
\hline & $\begin{array}{l}\text { arthritis, rheumatoid arthritis, } \\
\text { etc.) }\end{array}$ & 9 & 20.00 \\
\hline & f. None & & \\
\hline \multirow{5}{*}{4} & Drugs consumption & & \\
\hline & a. OAD & 15 & 33.33 \\
\hline & Anti-HT & 11 & 24.44 \\
\hline & None & 16 & 35.56 \\
\hline & $\begin{array}{l}\text { Others (analgesic, } \\
\text { bronchodilator, etc.) }\end{array}$ & 12 & 26.67 \\
\hline \multirow{5}{*}{5} & Body Mass Index (BMI) & & \\
\hline & a. Normal (18.5-22.9) & 15 & 33.33 \\
\hline & Underweight $(<18.5)$ & 3 & 6.67 \\
\hline & Overweight (23-29.9) & 19 & 42.22 \\
\hline & d. $\quad$ Obesity $(\geq 30)$ & 8 & 17.78 \\
\hline \multirow{4}{*}{6} & Body appearance & & \\
\hline & a. Ideal & 17 & 37.78 \\
\hline & b. Fat & 22 & 48.89 \\
\hline & Thin & 6 & 13.33 \\
\hline
\end{tabular}

Surprisingly, most respondents reported no family history of DM. This result was supported by a prospective study towards 3,570 Japanese workers aged 35-55 years old which showed that 121 individuals (3.4\%) reported new cases of DM after a year. Those with no family history of DM and sleep duration of $\leq 5$ hours developed DM with Odds Ratio (OR) of 5.37 if compared to sleep duration of $>7$ hours. Other risk factors were awakening during the night $(\mathrm{OR}=5.03)$, self-perceived insufficient sleep duration $(\mathrm{OR}=6.76)$, and unsatisfactory overall quality of sleep $(\mathrm{OR}=3.71)$ [29]. This means although we had no family history of DM but we lacked of sleep for years then there will be a high possibility to develop DM.

Duration of DM was mostly 1-5 years. DM duration has many implications, especially in the development of disease complication. A prospective study towards 3,298 stroke-free participants in which $22 \%$ had DM at baseline and $10 \%$ had development of DM showed that $7.4 \%$ respondents developed ischemic stroke after 9 years. DM was considered as time-dependent covariate and associated with stroke risk. Therefore, duration of DM was associated with ischemic stroke [30]. In this study, we found 8.89\% respondents had stroke.

Other than stroke, the comorbidity of HT was found in the majority. Morbidity rate of elderly in 2015 was $28.62 \%$, meaning there were 28 sick elderly every 100 elderly population, in which HT was the highest NCD found in elderly [22]. Therefore, it is very common to find elderly with HT in today's society. Cardiovascular disease (CVD), such as HT and stroke, had a stronger negative impact on QOL than did any 
other single disease, such as DM. The impact of comorbid diseases was greater than that of any single disease, except DM [31].

Most respondents also reported no consumption of drugs. This potentially happened because of medication nonadherence. A study towards 866 adults with DM in primary care setting showed that depression increased the rate of medication nonadherence, predicted problems of health-related behavior, and unsatisfactory glycemic control [32]. Another prospective study towards 740,195 veterans with type 2 DM showed that medication nonadherence was associated with $41 \%$ higher inpatient cost due to hospitalization [33]. The nonadherence to DM therapy is highly potential to cause disease complication due to bad glycemic control.

The majority perceived that they had a fat body, and the fact was true because their BMI was mostly 23-29.9 (overweight). Many people with DM are found to be overweight or obese and are not adherent to the given therapy, resulting in hyperglycaemia and additional medical therapy is needed to treat the disease. Overweight and obesity along with physical inactivity have been long recognized as the predisposing factor of DM. A meta-analysis towards 18 prospective cohort studies targeting overweight and obese population showed that the relative risk of developing DM type 2 was 7.28: 6.47, 8.28 for obesity and 2.92: 2.57, 3.32 for overweight [34]. Health professionals usually give advices like lifestyle modification in order to decrease the body weight. A study towards 5,145 diabetic people showed that the magnitude of weight loss at 1 year was strongly associated with improvements in glycaemia, blood pressure, tryiglycerides, and HDL cholesterol [35]. Most respondents were fully active and did sufficient self-care activity at home although they were under moderate stress level, but they had bad sleep quality. In the end, most of them had hyperglycemia. Table 3 explains the data of measured variables in details.

Table 3. Specific data of measured variables

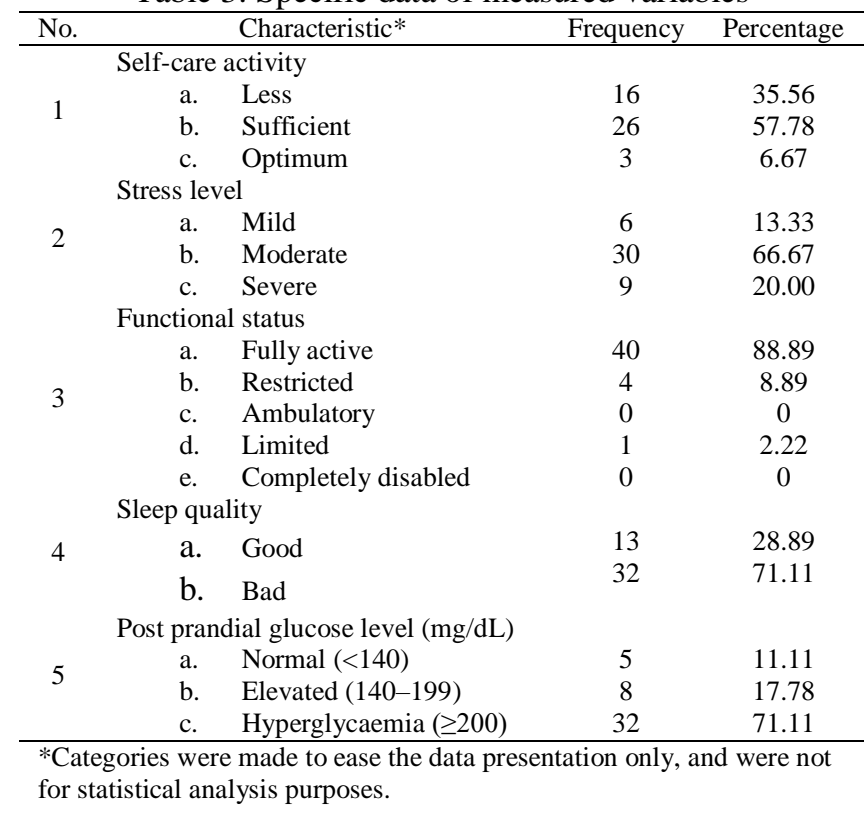

Most respondents did sufficient self-care. It can be assumed that most respondents felt really hard to do optimum self-care at home. We found only $6.67 \%$ respondents who succeeded in doing self-care activity. This potentially happened because of psychological problem, such as depression and anxiety. A study towards 312 adults with DM showed that anxiety was positively correlated with age, complications, diabetes education difficulty, and depression; therefore it was recommended to address psychosocial needs of people with DM in order to improve effects of patient education and disease self-management or self-care [36].

The majority reported moderate stress level stated that there are many life events inducing individual stress, one of them is physical disease, especially the chronic one [37] DM for instance. When stress is experienced in the postprandial period, acute psychological stress significantly increases glucose concentrations in patients with type 2 DM [38]. In the other hand, we found most respondents also had bad sleep quality. Experimental reduction of the duration or quality of sleep has a deleterious effect on glucose metabolism because it downregulates the satiety hormone, leptin, upregulates the appetite-stimulating 
hormone, ghrelin, and increases hunger and appetite [39]. Therefore, it was expected to found most respondents with psychological stress, bad sleep quality, and hyperglycaemia in this study.

DM was not interfere life functioning, therefore most respondents were fully active. Elderly living with DM still can do normal daily living activity, although sometimes it was limited due to the geriatric syndrome. DM is associated with an increased prevalence and incidence of geriatric syndrome which becomes a major obstacle in the treatment and care of diabetic people [40]. Although most published study reported DM increases the disability in elderly, but this was not found in our respondents. There is a high possibility that the weekly physical exercise (elderly gymnastic) they did in the elderly community health group supervised by Mulyorejo PHC gave them a good impact on body fitness and functional status. Exercise improves blood glucose control in type $2 \mathrm{DM}$, reduces cardiovascular risk factors, contributes to weight loss, and improves well-being; the adoption and maintenance of physical activity are critical foci for blood glucose management and overall health in individuals with diabetes and prediabetes [41].

In DM, especially type 2, the measurement of PPG level could predict cardiovascular events and all-cause mortality [42]. Fluctuations in blood glucose levels play a significant role in vascular endothelial dysfunction in type 2 DM [43]. In this study, we found most respondents had HT, while some had heart disease and stroke. This result emphasizes the importance of PPG level measurement periodically to prevent DM complications. Our respondents potentially had hyperglycaemia for some period of time; therefore those DM complications existed in the time of data collection. Blood glucose monitoring is one pillar of all 7 pillars of self-care for diabetic people. Their ability to use glucometer properly can have great influence on the accuracy of blood glucose measurement. Accuracy may be limited due to strip manufacturing variances, strip storage, and aging. They may also be due to limitations on the environment such as temperature or altitude or to patient factors such as improper coding, incorrect hand washing, altered hematocrit, or naturally occurring interfering substances. Finally, exogenous interfering substances may contribute errors to the system evaluation of blood glucose [44].

The data of self-care activity, sleep quality, stress level, and PPG level were normally distributed ( $\mathrm{p}=.912, \mathrm{p}=.122, \mathrm{p}=.178$, and $\mathrm{p}=.475$ respectively), so that Pearson correlation test could be in data analysis. Only the data of functional status which was not normally distributed ( $\mathrm{p}=.000)$, therefore Spearman Rank correlation test was used in statistical analysis involving this variable. Results showed that functional status, self-care activity, sleep quality, and stress level were not significantly correlated with PPG level in diabetic elderly ( $\mathrm{p}=.245, \mathrm{p}=.776, \mathrm{p}=.937$, and $\mathrm{p}=.349$ respectively), therefore these four variables could not be PPG level predictors.

We cannot deny the factor of food intake in predicting the PPG level. A systematic review towards 21 articles indicated that the consumption of fat and protein modify postprandial glycemia because high-fat/protein meals require more insulin than lower-fat/protein meals with identical carbohydrate content [45]. A prospective study towards 100 diabetic people revealed that gut microbiota could accurately predicts personalized postprandial glycemic response to real-life meals; having a personalized meals was adviced to the diabetic individual [46]. In the other hand, a study towards ten inactive, overweight or obese adults with DM showed that a single session of high-intensity interval training has greater and more lasting effects on reducing incremental PPG level when compared with continuous moderate-intensity interval training [47]. There is a high possibility if most overweight respondents in this study had hyperglycemia due to inappropriate intensity of exercise they did every week, and none of them had personalized meals everyday; they usually eat the same menu with another family member.

The factors that influence PPG level consist of internal and external factors. Internal factors consist of insulin, glucose, and cortisol, as a receptor system in the muscles and liver cells; while external factors consist of food consumed and physical activity [48]. Argues that exercise can reduce insulin resistance so that insulin can function normally for cells in the body and burn fat to prevent the occurrence of obesity [49]. Foods that contain high carbohydrates and fiber can affect pancreatic beta cells in producing insulin and consuming excess fat can also affect insulin sensitivity. Consuming alcohol can increase PPG level because it contains high sugar level. Individuals who have good dietary knowledge can control their blood sugar levels well [50]. DM-related knowledge was not assessed in this study.

Psychologically, co-morbid diseases can trigger anxiety which results in disruption of the hormone system in the body so that it can increase PPG level [51]. Anxiety is a response to chronic illnesses that are suffered, considered as a pressure, discomfort, anxiety and disappointment. These psychological disorders make diabetic people become indifferent to the rules of treatment that must be carried out, such as diet, medical therapy, and physical exercise so PPG level are not controlled properly. In the other hand, an increased prevalence of depressive disorders, often comorbid with anxiety, has been reported in patients with DM. The prevalence of major depression in patients with DM is mostly estimated around $12 \%$ (ranging from $8-18 \%$ ), while milder types of depression or elevated depressive symptoms, in general, are reported to be present in $15-35 \%$ [52]. 
We found some limitation in this study. Regarding study instruments, cultural issue was not addressed. There is a possibility that functional status, self-care activity, sleep quality, and stress level are influenced by cultural context in elderly who live in the community. In the other hand, the design of Cross-sectional study has limitation regarding follow up. Therefore the changes in variables' value were not measured from time to time to see the fluctuation of score and factors influencing those changes.

\section{CONCLUSION}

Functional status, self-care activity, sleep quality, and stress level were not significantly correlated with PPG level in diabetic elderly. These four variables could not be PPG level predictors, especially in diabetic elderly who live in the city. Other factors may play a more important role in predicting PPG level but unidentified in this study. These study findings contradict the results of previous studies which indicating that functional status, self-care activity, sleep quality, and stress level were contributing factors of glycemic control in diabetic people. More studies are needed to determine the factors strongly predicting PPG level in diabetic elderly, especially in those who live in the city.

\section{ACKNOWLEDGEMENTS}

This study was funded and supported for publication by Faculty of Nursing, Widya Mandala Catholic University Surabaya.

\section{REFERENCES}

[1] World Health Organization (WHO), "What are NCD and Their Risk Factors?," 2019. Retrieved from: http://www.who.int/ncds/en

[2] L. R. Manas, A. J. Sinclair, "Diabetes and Functional Limitation: The Emergence of Frailty and Disability," Diabetes in Old Age, 4th Edition, by: A. J. Sinclair, T. Dunning, L. R. Manas, M. Munshi, 2017.

[3] Lukman, "Diabetes Mellitus in South Sulawesi (in Bahasa Indonesia)," 2015. Jakarta: Yayasan Pustaka Obor.

[4] R. Bilous, "Diabetes Handbook (in Bahasa Indonesia), 4th Edition” 2014. Jakarta: Bumi Medika.

[5] Agency of Research and Development, Ministry of Health, Republic of Indonesia, "Basic Health Research (in Bahasa Indonesia)," $2013 . \quad$ Retrieved http://www.depkes.go.id/resources/download/general/Hasi1\%20Riskesdas\%202013.pdf

[6] Kusnanto, "Improving Psychosocial-spiritual Response in Patients with Type 2 Diabetes Mellitus (in Bahasa Indonesia)," Jurnal Ners, vol.8, no.1, pp.47-55, 2013.

[7] T. Holt, S. Kumar, “ABC of Diabetes, 6th Edition,” 2010. New Jersey: Blackwell Publishing.

[8] Padila, "Nursing Care Plan for Internal Disease (in Bahasa Indonesia)," 2013. Yogyakarta: Nuha Medika.

[9] S. R. Shrivastava, P. S. Shrivastava, J. Ramasamy, "Role of Self-care in Management of Diabetes Mellitus," Journal of Diabetes \& Metabolic Disorders, vol.12, no.14, 2013.

[10] E. V. Cauter, K. Spiegel, E. Tasali, R. Leproult, "Metabolic Concequences of Sleep and Sleep Loss," Sleep Medicine, vol.9, supp.1, pp.S23-S28, 2008.

[11] K. Spiegel, R. Leproult, E. V. Cauter, "Impact of Sleep Debt on Metabolic and Endocrine Function,” The Lancet, vol.354, no.9188 pp.1435-1439, 1999.

[12] P. A. Potter, A. G. Perry, "Fundamental of Nursing: Concept, Process and Practice, 7th Edition, Vol.3," 2010. Jakarta: EGC.

[13] P. M. Nilsson, "Cardiovascular Risk Factors: Hypertension,” Textbook of Diabetes, 5th Edition, 2016. Retrieved from: https://e-resources.perpusnas.go.id:2619/doi/pdf/10.1002/9781118924853.ch42

[14] N. P. W. P. Sari, J. Artsanthia, "Comparison of Stress Level and Quality of Life in Elderly Who are Living with Chronic Illness in Bangkok and Surabaya," The Book of Abstracts of The 9th International Nursing Conference: Nurses at The Forefront Transforming Care, Science and Research, 2018. Surabaya: Faculty of Nursing, Universitas Airlangga.

[15] L. Triana, M. Salim, "Differences on Postprandial Blood Glucose Level (in Bahasa Indonesia)," Jurnal Laboratorium Khatulistiwa, vol.1, no.1, pp.51-57, 2017.

[16] M. M. Oken, R. H. Creech, D. C. Tormey, J. Horton, T. E. Davis, E. T. McFadden, P. P. Carbone, "Toxixity and Response Criteria of The Eastern Cooperative Oncology Group," Am. J. Clin. Oncol., vol.5, no.6, pp.649-655, 1982.

[17] P. K. Gatlin, "Dissertation: Severity of Type 2 Diabetes Mellitus, Working Memory, and Self-care," 2012. Retrieved from: www.arizona.openrepository.com

[18] D. J. Buysse, C. F. Reynolds 3rd, T. H. Monk, S. R. Berman, D. J. Kupfer, "The Pittsburgh Sleep Quality Index: A New Instrument for Psychiatric Practice and Research,” Psychiatry Res., vol.28, no.2, pp.193-213, 1989.

[19] J. Artsanthia, N. P. W. P. Sari, "Study Report: The Effects of Meditation Healing Exercise in Elderly Who are Living with Non-communicable Disease in Bangkok and Surabaya," 2017. Bangkok: Faculty of Nursing, Saint Louis College.

Int. J. Public Health Sci. Vol. 8, No. 2, June 2019: 254 - 262 
[20] A. Walker, "Quality of Life in Old Age in Europe," 2009. Retrieved from: https://www.mheducation.co.uk/openup/chapters/0335215149.pdf

[21] World Health Organization (WHO), "Non-Communicable Diseases Progress Monitor 2015 (September 2015)," 2015. Geneva: WHO.

[22] Ministry of Health, Republic of Indonesia, "Analysis of Elderly in Indonesia (in Bahasa Indonesia), 2017. Retrieved from: http://www.depkes.go.id/download.php?file=download/pusdatin/lainlain/Analisis\%20Lansia\%20Indonesia\%202017.pdf

[23] Ministry of Health, Republic of Indonesia, "Info Datin: Hypertension, Health Department, Republic of Indonesia, Jakarta (in Bahasa Indonesia),” 2015. Retrieved from: http://www.depkes.go.id/folder/view/01/structure-publikasipusdatin-info-datin.html

[24] L. F. Macha-Quillama, A. E. Samanamu-Leandro, D. C. Rodriguez-Hurtado, "Health Literacy and Associated Factors in Patients Attending the Outpatient Internal Medicine Service of a National Hospital of Lima, Peru," Rev. Salud Publica, vol.19, no.5, pp.679-685, 2017.

[25] H. E. Hemming, L. Langille, "Building Knowledge and Literacy in Health," Canadian Journal of Public Health, vol.97, pp.s31-s36, 2006.

[26] E. H. Lee, Y. W. Lee, S. H. Moon, “A Structural Equation Model Linking Health Literacy to Self-efficacy, Selfcare Activities, and Health-related Quality of Life in Patients with Type 2 Diabetes," Asian Nursing Research, vol.10, pp. 82-87, 2016

[27] Educational Bodies and Financial Training / BPPK, Ministry of Moneytary, Republic of Indonesia, "Medium Class Income Arise $=$ Potential Tax (in Bahasa Indonesia)," 2015. Retrieved from: https://bppk.kemenkeu.go.id/publikasi/artikel/167-artikel-pajak/21014-penghasilan-kelas-menengah-naik-potensipajak

[28] J. Kumar, "Gender Dimension of Quality of Life among Elderly in India," 2012. Retrieved from: https://paa.confex.com/paa/.../Gender\%20Dimension\%20Quality\%200f\%20life.pdf

[29] T. Kita, E. Yoshioka, H. Satoh, Y. Saijo, M. Kawaharada, E. Okada, R. Kishi, "Short Sleep Duration and Poor Sleep Quality Increase the Risk of Diabetes in Japanese Workers with No Family History of Diabetes," Diabetes Care, vol.35, no.2, pp.313-318, 2012.

[30] C. Banerjee, Y. P. Moon, M. C. Paik, T. Rundek, C. Mora-McLaughlin, J. R. Vieira, R. L. Sacco, M. S. V. Elkind, "Duration of Diabetes and Risk of Ischemic Stroke: The Northern Manhattan Study," Stroke, vol.43, no.5, pp.12121217, 2012.

[31] Y. R. Chin, I. S. Lee, H. Y. Lee, "Effects of Hypertension, Diabetes, and/or Cardiovascular Disease on HealthRelated Quality of Life in Elderly Korean Individuals: A Population-based Cross-sectional Survey,“ Asian Nursing Research, vol.8, no.4, pp.267-273, 2014.

[32] J. Dirmaier, B. Watzke, U. Koch, H. Schulz, H. Lehnert, L. Pieper, H. U. Wittchen, "Diabetes in Primary Care: Prospective Associations between Depression, Nonadherence, and Glycemic Control," Psychother Psychosom, vol.79, pp.172-178, 2010

[33] L. E. Egede, M. Gebregziabher, C. E. Dismuke, C. P. Lynch, R. N. Axon, Y. Zhao, P. D. Mauldin, "Medication Nonadherence in Diabetes: Longitudinal Effects on Costs and Potential Cost Savings from Improvement," Diabetes Care, vol.35, no.12, pp.2533-2539, 2012.

[34] A. Abdullah, A. Peeters, M. de Courten, J. Stoelwinder, "The Magnitude of Association between Overweight and Obesity and The Risk of Diabetes: A Meta-analysis of Prospective Cohort Studies," Diabetes Research and Clinical Practice, vol.89, no.3, pp.309-319, 2010.

[35] R. R. Wing, W. Lang, T. A. Wadden, M. Safford, W. C. Knowler, A. G. Bertoni, J. O. Hill, F. L. Brancati, A. Peters, L. Wagenknecht, the Look AHEAD Research Group, "Benefits of Modest Weight Loss in Improving Cardiovascular Risk Factors in Overweight and Obese Individuals with Type 2 Diabetes," Diabetes Care, vol.34, no.7, pp.1481-1486, 2011.

[36] S. F. Wu, Y. C. Huang, S. Y. Liang, T. J. Wang, M. C. Lee, H. H. Tung, "Relationships among Depression, Anxiety, Self-care Behaviour and Diabetes Education Difficulties in Patients with Type-2 Diabetes: a Crosssectional Questionnaire Survey," Int J Nurs Stud, vol.48, no.11, pp.1376-1383, 2011.

[37] D. Hawari, "Stress, Depression, and Anxiety (in Bahasa Indonesia)," 2002. Jakarta: EGC.

[38] M. Faulenbach, H. Uthoff, K. Schwegler, G. A. Spinas, C. Schmid, P. Wiesli, "Effect of Psychological Stress on Glucose Control in Patients with Type 2 Diabetes," Diabetic Medicine, vol.29, no.1, pp.128-131, 2011.

[39] K. Spiegel, E. Tasali, R. Leproult, E. V. Cauter, "Effects of Poor and Short Sleep on Glucose Metabolism and Obesity Risk," Nature Reviews Endocrinology, vol.5, pp.253-261, 2009.

[40] A. Araki, H. Ito, "Diabetes Mellitus and Geriatric Syndromes," Geriatrics Gerontology International, vol9, no.2, pp.105-114, 2009.

[41] S. R. Colberg, R. J. Sigal, J. E. Yardley, M. C. Riddell, D. W. Dunstan, P. C. Dempsey, E. S. Horton, K. Castorino, D. F. Tate, "Physical Activity/Exercise and Diabetes: A Position Statement of The American Diabetes Association," Diabetes Care, vol.39, no.11, pp.2065-2079, 2016.

[42] F. Cavalot, A. Pagliarino, M. Valle, L. D. Martino, K. Bonomo, P. Massucco, G. Anfossi, M. Trovati, "Postprandial Blood Glucose Predicts Cardiovascular Events and All-cause Mortality in Type 2 Diabetes in A 14-year Followup," Diabetes Care, vol.34, no.10, pp.2237-2243, 2011.

[43] K. Torimoto, Y. Okada, H. Mori, Y. Tanaka, "Relationship Between Fluctuations in Glucose Levels Measured by Continuous Glucose Monitoring and Vascular Endothelial Dysfunction in Type 2 Diabetes Mellitus," Cardiovascular Diabetology, vol.12, no.1, pp.1-7, 2013. 
[44] B. H. Ginsberg, "Factors Affecting Blood Glucose Monitoring: Sources of Errors in Measurement," Journal of Diabetes Science and Technology, vol.3, no.4, pp.903-913, 2009.

[45] K. J. Bell, C. E. Smart, G. M. Steil, J. C. Brand-Miller, B. King, H. A. Wolper, "Impact of Fat, Protein, and Glycemic Index on Postprandial Glucose Control in Type 1 Diabetes: Implications for Intensive Diabetes Management in The Continuous Glucose Monitoring Era," Diabetes Care, vol.38, no.6, pp.1008-1015, 2015.

[46] D. Zeevi, T. Korem, N. Zmora, D. Israeli, D. Rothschild, A. Weinberger, O. Ben-Yacov, D. Lador, T. Avnit-Sagi, M. Lotan-Pompan, J. Suez, J. A. Mahdi, E. Matot, G. Malka, N. Kosower, M. Rein, G. Zilberman-Schapira, L. Dohnalova, E. Segal, "Personalized Nutrition by Prediction of Glycemic Responses," Cell, vol.163, no.5, pp.10791094, 2015.

[47] J. P. Little, M. E. Jung, A. E. Wright, W. Wright, R. J. F. Manders, "Effects of High-intensity Interval Exercise Versus Continuous Moderate-intensity Exercise on Postprandial Glycemic Control Assessed by Continuous Glucose Monitoring in Obese Adults," Applied Physiology, Nutrition, and Metabolism, vol.39, no.7, pp.835-841, 2014.

[48] R. Lestari, T. A. Wihastuti, B. F. Rahayu, "The Correlation Between Anxiety and Independence Level of Daily Living Activity in Institutionalized Elderly (in Bahasa Indonesia)," Journal of Nursing Science, vol.1, no.2, pp.128134, 2013.

[49] C. Fox, A. Kilvert, "Friendly with Type 2 Diabetes (in Bahasa Indonesia)," 2010. Depok, Jakarta: Penebar Plus.

[50] H. K. Özçelik, M. E. Akkoyunlu, P. Bostanl, M. Bayram, E. Atahan, M. Sezer, F. Karaköse, L. Kart, "The Frequency and Properties of REM Related Obstructive Sleep Apnea among The Patients with Mild Related Obstructive Sleep Apnea," 2013. Retrieved from: http://www.tuberktoraks.org/linkout.aspx?pmid=24506743

[51] H. Tandra, "Everything You Need to Know about Diabetes (in Bahasa Indonesia)," 2007. Surabaya: EGC.

[52] E. Andreoulakis, T. Hyphantis, D. Kandylis, A. lacovides, "Depression in Diabetes Mellitus: A Comprehensive Review," Hippokratia, vol.16, no.3, pp.2015-214, 2012. 